\title{
Role of catastrophic disturbance in mediating Nucella-Mytilus interactions in the Alaskan rocky intertidal
}

\author{
Michael L. Carroll*, Raymond C. Highsmith \\ Institute of Marine Science, University of Alaska Fairbanks, Fairbanks, Alaska 99775-7220, USA
}

\begin{abstract}
The mussel Mytilus trossulus is typically a dominant competitor and principal spaceoccupying species in the rocky mid-intertidal zone of south central Alaskan (USA). Its principal predator in the region is the whelk Nucella lima. We examined predator-prey interactions between $M$. trossulus and $N$. lima following a severe freeze which greatly reduced mussel abundance in the upper portion of their vertical range. N. lima in Kachemak Bay was locally abundant, but its spatial distribution was patchy, resulting in site-to-site variation in predation intensity. Following the freeze, mussel populations recovered to occupy $72 \%$ of primary space at a site where $N$. lima was rare. At sites where $N$. lima occurred in high densities $\left(>100 \mathrm{~m}^{-2}\right)$, mussel cover remained significantly lower. At the latter sites, up to $81 \%$ of mussel mortality was due to snail predation. In field trials, average densities of $N$. lima significantly reduced mussel cover within $2 \mathrm{wk}$. From published literature on Nucella sp. feeding rates and our data on in situ reductions in mussel beds, we estimate that $N$ lima can eliminate 60 to $90 \%$ of mussels at a given site in 1 season. In contrast to the general view that mussel recovery from disturbance is inevitable, our results indicate that local populations of young mussels were unable to increase space utilization because of intense $N$. lima predation. A stochastic, catastrophic disturbance event thus altered control of community structure by removing dense stands of large prey individuals that had grown to near-refuge size. This facilitated long-term $N$. lima control of what had been a mussel-dominated community by shifting the interaction toward smaller sized mussels that are susceptible to intense predation.
\end{abstract}

KEY WORDS: Alaska - Community structure - Disturbance - Indirect effects - Rocky intertidal Predation Mytilus $\cdot$ Nucella

\section{INTRODUCTION}

Interspecific interactions occur within an environmental framework set by species' tolerances of the physical parameters characteristic of a particular habitat. Superimposed upon such characteristic patterns of environmental variability are episodic disturbance events (Connell 1978, Sousa 1979, 1984, Dethier 1984). At one end of a disturbance continuum are chronic, low-intensity, and relatively predictable events to which species may be able to adjust. At the other end

\footnotetext{
- Present address: International Atomic Energy Agency, Marine Environment Laboratory, 19 Avenue des Castellans, MC-98012 Monaco. E-mail: carroll@unice.fr
}

of the continuum are catastrophic events which are acute, rare, and unpredictable, and which affect many species, cause extensive mortality, and at least temporarily alter community structure (Harper 1977 , Dethier 1984). Such stochastic disturbances may influence community structure directly via induced mortality and/or indirectly through alteration of interactions between component species (Knowlton et al. 1981, Menge 1995). Further, effects of disturbances may be exacerbated in species living in sub-optimal habitats at or near their limits of physiological tolerance (Bowman \& Lewis 1977, Lewis et al. 1982, Sousa 1984).

Rocky intertidal habitats are particularly amenable to examining the influences of physically induced disturbances on species distributions and interactions 
because physical gradients are spatially compressed and often well defined. Also, many rocky intertidal species are sessile or have limited mobility, making them easy to observe and manipulate across gradients.

Mussels are common constituents of rocky intertidal communities throughout the world (Soot-Ryen 1955, Seed 1976, Suchanek 1986, Gosling 1992). The broad success of mytilids is due largely to their life-history characteristics. Mussels settle densely and grow quickly to reproductive size, often occupying 75 to $80 \%$ of the substratum soon after settlement to unoccupied space (Suchanek 1978). These characteristics, combined with their relative mobility compared to other space-occupying intertidal species, lead to the mussels' competitive superiority (Paine 1966, Menge 1976, Seed 1976, Lubchenco \& Menge 1978), often resulting in extensive mussel bands on many rocky shorelines (Stephenson \& Stephenson 1972, Ricketts et al. 1985, Suchanek 1986).

Mussels are preyed upon by a variety of invertebrate and vertebrate predators including snails, sea stars, crabs, fish, sea otters, sea birds and shore birds (Paine

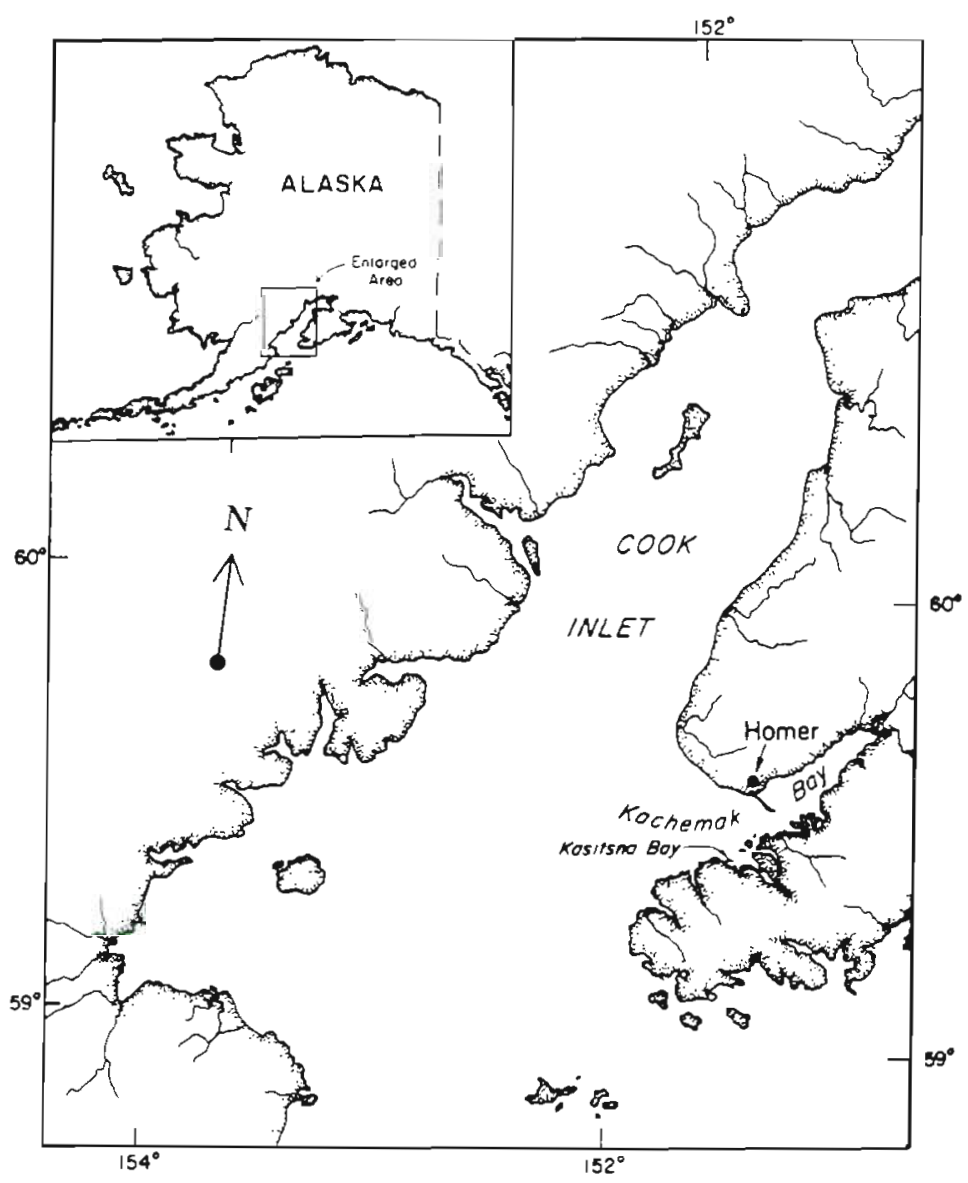

Fig. I Map showing location of Kachemak Bay in south central Alaska (USA)
1966, 1974, Suchanek 1986, Menge et al. 1994). Predation by sea stars and whelks in particular has been shown to set the lower extent of mussel distribution in intertidal habitats throughout the world (Seed 1969, Paine 1974, Suchanek 1986). Despite predation pressure, established mussel populations often persist on shorelines in a refuge zone above the level of greatest predator abundance. As a result, predator control of mussel populations over their entire vertical range on the shore is rare.

Mytilus trossulus Gould occurs on the west coast of North America from California, where it hybridizes with M. galloprovincialis Lamarck (McDonald \& Koehn 1988, Koehn 1991, McDonald et al. 1991, review in Gosling 1992), to Alaska. At temperate latitudes, on exposed mid- to low intertidal sites, $M$. trossulus is competitively subordinate to $M$. californianus Conrad and is primarily restricted to disturbancecreated refuges in $M$. californianus beds, and habitats less exposed to wave action (Suchanek 1978, 1979, 1981). In Alaska, however, $M$. californianus is not abundant and $M$. trossulus is the dominant band-forming mussel in the littoral zone (Feder et al. 1977, Feder \& Keiser 1980, O'Clair \& Zimmerman 1987, Seed \& Suchanek 1992). The success of $M$. trossulus in occupying rocky intertidal space over large geographical areas is due, in part, to its tolerance of a wide range of environmental conditions including high and low temperatures (Seed 1969, Suchanek 1986, Seed \& Suchanek 1992).

In Kachemak Bay, south central Alaska (Fig. 1), the principal predator on Mytilus trossulus is the predatory gastropod Nucella lima (Gmelin) (Kincaid 1964). N. lima occupies a broad vertical range in the mid-intertidal zone which overlaps that of $M$. trossulus. Other benthic predators occur in low densities or in low intertidal zones not overlapping with mussels (M. L. Carroll pers. obs.).

In January, 1989, an extended ( $3 \mathrm{wk}$ ) severe freeze occurred along the south central Alaskan coast, with recorded temperatures as low as $-31^{\circ} \mathrm{C}$ (NOAA 1994), and coincided with a spring low tide series (Fig. 2), The freeze was a large-scale disturbance event on the North American west coast, as its effects on intertidal mussel populations were noted several thousand $\mathrm{km}$ to the south of the study site (Seed \& Suchanek 1992, Robles et al. 1995). This event substantially altered the structure of Alaskan rocky intertidal communities by causing 


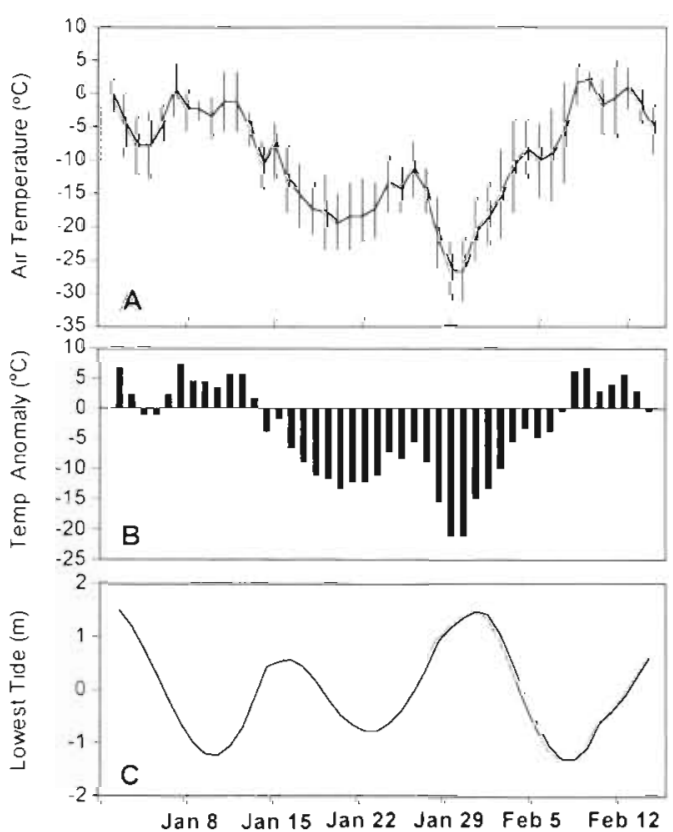

Fig. 2. Temperature and tide data from Homer, Alaska during January and February 1989: (A) daily average temperatures and temperature ranges (indicated by bars); $(B)$ the deviation from historical average temperatures (a negative anomaly indicates colder than normal temperatures); and (C) the lowest daily tide level during that time period

extensive mortality of many resident species (Carroll 1994). Mytilus trossulus suffered nearly total mortality in the upper intertidal zone where it had previously dominated (R. C. Highsmith unpubl. data). Nucella lima was not as severely affected because it winters at lower levels in the intertidal (M. L. Carroll pers. abs.). Since the freeze, patterns of mussel recovery have been atypical compared to their usual recruitment patterns and growth characteristics. Although rates of recovery from disturbance in mussel beds vary, the process is thought to be deterministic (Suchanek 1986). with mussels predictably returning to dominance. However, more than 3 yr after large numbers of mussels were removed from the community, the characteristic mussel zone on shorelines of Kachemak Bay was rare and patchy.

In this paper, we report on observational and experimental field studies designed to reveal mechanisms responsible for the minimal post-disturbance recovery of mussel populations at many locations in Kachemak Bay. Specifically, we tested the hypothesis that intense predation by Nucella lima was responsible for the delayed recovery of Mytilus trossulus and its failure to regain spatial dominance. Further, we explore the indirect role of the disturbance event in influencing community structure through long-term alteration of predator-prey interactions between resident species.

\section{METHODS}

Density, cover, and size determinations. Long-term trends in mussel cover were estimated from July 1989 through August 1992 by analyzing time-series photographs of permanent quadrats at 2 sites separated by 5 km: Kasitsna Bay and Hesketh Island (Carroll 1994).

Nucella lima abundance was determined monthly from April to July 1992 and again in December 1993. Initially, N. lima density was estimated in Kasitsna Bay, a small pocket embayment on the south shore of Kachemak Bay (Fig. 1), at 2 locations separated by approximately $200 \mathrm{~m}$. N. lima densities were determined from 10 to 30 randomly located $0.25 \mathrm{~m}^{2}$ quadrats which were cast blindly in the vertical zone of $N$. lima's greatest occurrence $(+1.5$ to $3.5 \mathrm{~m})$. The number of randomly located quadrats varied per census, but an equal number of quadrats were examined at each site during a given census. Snails in the quadrats were counted and measured to the nearest $1 \mathrm{~mm}$. Snail size was measured as the length of the shell from the apex to the end of the siphonal canal (total length along the axis of coiling).

In July 1992, Nucella lima density was estimated using the procedure described above at both Kasitsna Bay and Nubble Point. Nubble Point is a semi-exposed rocky outcropping approximately $2 \mathrm{~km}$ from the Kasitsna Bay sites and is isolated from neighboring rocky intertidal habitats by several hundred meters of sand and gravel beaches. This buffer of highly mobile substrate effectively eliminates immigration from neighboring sites by species such as $N$. lima with non-dispersing larvae and crawl-away young. However, such a barrier does not affect species with dispersive larvae such as Mytilus trossulus.

In the same quadrats ( $\mathrm{n}=30$ ) that were censused for Nucella lima density, cover of Mytilus trossulus was estimated using a point frame method. A $0.25 \mathrm{~m}^{2}$ frame with a grid of 81 evenly spaced points (every $5 \mathrm{~cm}$ on each axis) was placed over the quadrat and aligned with corner markers. Percent cover was determined as the number of points directly over mussels relative to the total number of points in the grid. All cover data were subjected to an arcsine square root transformation prior to analysis to normalize the distribution of percentages (Sokal \& Rohlf 1981). Error intervals are presented as 1 standard error of the mean unless otherwise indicated.

Causes of Mytilus trossulus mortality. To estimate the proportion of mussel mortality attributable to Nucella lima predation versus other sources of mortality, the valves of dead mussel shells were examined at Kasitsna Bay and Nubble Point. Nucella spp. attack mussels by drilling a small hole through one of the valves (Carriker \& van Zandt 1972); hence, mortality 
resulting from $N$. lima predation is easily distinguishable from other mortality sources.

The first 100 empty Mytilus trossulus shells encountered in each of 2 size classes $(<25 \mathrm{~mm},>25 \mathrm{~mm})$ at Kasitsna Bay and Nubble Point were inspected for drill holes caused by Nucella lima predation. Only shell remains with both valves present were included in the analysis because including shells with single valves would potentially bias the results.

Effect of Nucella lima predation on Mytilus trossulus. The role of $N$. lima in regulating mussel populations in situ was determined by experimentally manipulating the density of snails in mussel beds. Cages were used to maintain constant snail densities at test sites in mussel beds.

Cages $(20 \times 20 \times 10 \mathrm{~cm})$, made of $0.635 \mathrm{~cm}$ mesh galvanized steel hardware cloth, were placed in mussel beds at Kasitsna Bay where initial mussel cover exceeded $90 \%$. Average sizes of mussels in beds where cages were placed $(27.9 \pm 1.52 \mathrm{~mm} ; \mathrm{n}=40)$ were consistent (ANOVA: $\mathrm{df}=1,78, F=1.49, p=0.23$ ) with the size of mussels outside cages $(25.6 \pm 1.13 \mathrm{~mm}$; $n=40$ ). Each cage was randomly assigned 1 of 3 Nucella lima density treatments: normal density $(5$ snails), high density (10 snails), and a control which contained no snails. $N$. lima densities used in cages were based on the average density $\left(131.6 \mathrm{~m}^{-2}\right)$ at that site. There were 8 replicates per treatment. The mean size of the snails $(17.65 \pm 0.25 \mathrm{~mm} ; \mathrm{n}=120)$ used in the cages was slightly smaller (ANOVA: $\mathrm{df}=1,452, F=$ 9.69, $p=0.0020$ ) than the size of the snails in the most recent census $(19.26 \pm 0.49 \mathrm{~mm} ; \mathrm{n}=334)$.

Mussel cover in the cages was estimated by overlaying a grid of 100 uniformly spaced points located on a clear acetate sheet atop the mussel bed within each cage, and determining the proportion of total points which were directly over mussels. Each cage was censused at the initiation of the experiment and every 2 wk during the 8 wk duration of the experiment.

\section{RESULTS}

\section{Temporal trends in Mytilus trossulus and Nucella lima abundance and demography}

In April 1989, less than 3 mo after the freeze, live mussels were rare in the mid-intertidal. Extensive stands of gaping mussel shells were still attached to rocks. Often, not a single live mussel was found in the shell beds. Also, conspicuous windrows of many thousands of mussel shells were commonly observed on beaches. By the summer of 1989, most of the dead mussel shells previously attached to rocks had fallen off or been washed away by wave action. Consequently, at

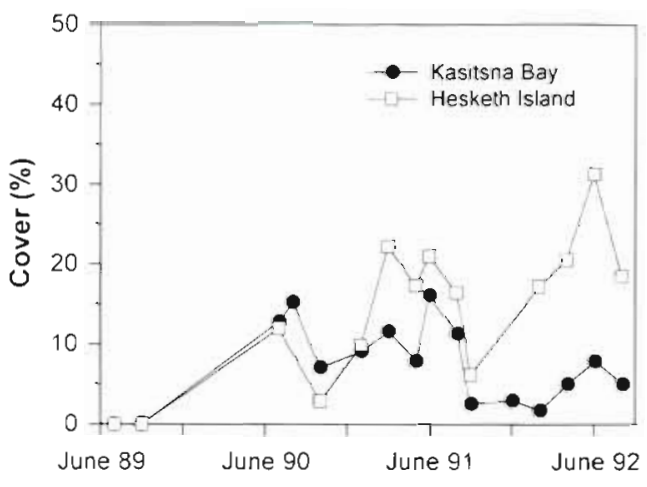

Fig. 3. Mean cover (\%) of the mussel Mytilus trossulus at 2 sites in Kachemak Bay from 1989-1992. $n=3$ quadrats per site. Error bars are omitted for graphical clarity

the beginning of this study, live mussels occupied essentially no space in a zone where they are normally abundant (Fig. 3), underscoring the severity of the impact of the freeze on mussel populations.

An increase in mussel cover due to recruitment was evident in the vertical zone of greatest abundance $(+1.5$ to $3.0 \mathrm{~m}$ mean lower low water) during the summer following the freeze (Fig. 3), but their occupation of space did not increase rapidly through high recruitment and growth as would be expected from the literature (Seed 1976, Lubchenco \& Menge 1978, Suchanek 1978). On the contrary, mussel cover decreased during the latter half of 1990 and through the spring of 1991. This pattern of moderate recruitment followed by a decline in cover was repeated in 1991 and 1992. As a result, more than 3.5 yr after the freeze, mussel cover had not increased appreciably at Kasitsna Bay, and had only modestly increased at Hesketh Island.

Nucella lima density varied between summer and winter. In winter, $N$. lima was scarce in the midintertidal at Kachemak Bay (December 1993: $0.80 \pm$ $0.37 \mathrm{~m}^{-2} ; \mathrm{n}=20$ ). The few snails found in the mid-intertidal were usually restricted to moist crevices and small tide pools. In April, N. lima density at both Kasitsna Bay sites (Fig. 4) was significantly less than during the 3 subsequent summer months (ANOVA, Site $1 \mathrm{df}=$ $1,48, F=81.89, \mathrm{p}<0.0001$; Site $2: \mathrm{df}=1,48, F=146.83$, $\mathrm{p}<0.0001$ ), indicating a transition between winter and summer densities. By May, densities had increased about 3-fold (Fig. 4), then remained relatively constant through the remainder of the summer (ANOVA, Site 1: $\mathrm{df}=2,27, F=1.14, P=0.34$; Site $2: \mathrm{df}=2,27, F=1.21$, $\mathrm{p}=0.31) . N$. lima size varied little through the study period, from $19.02 \pm 0.37 \mathrm{~mm}(\mathrm{n}=204)$ in April to 18.22 $\pm 0.22 \mathrm{~mm}(\mathrm{n}=455)$ in July, indicating that the observed increase in density during the summer was primarily due to movement of established individuals into the mid-intertidal from below. 


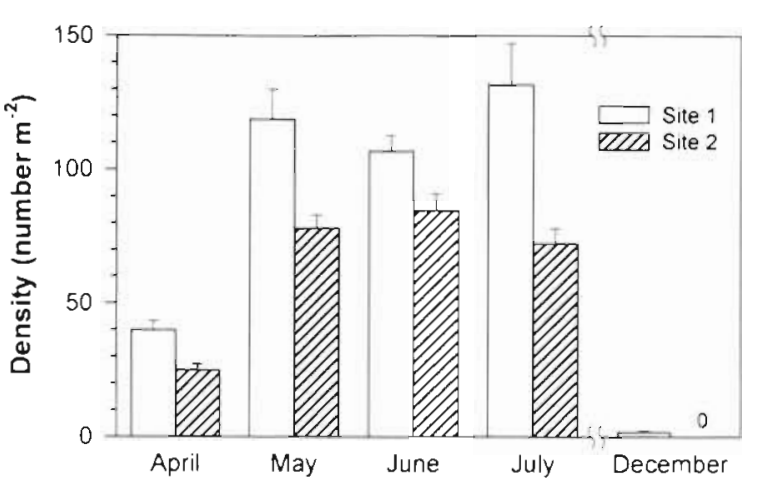

Fig. 4. Variation in Nucella lima density $(+\mathrm{SE})$ at 2 locations in Kasitsna Bay during the spring and summer of 1992 and December 1993
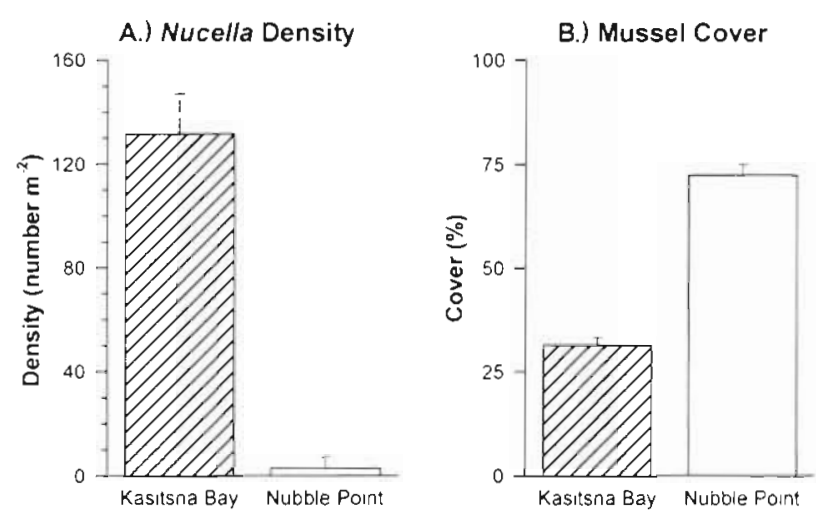

Fig. 5. (A) Nucella lima density and (B) Mytilus trossulus cover at Kasitsna Bay and Nubble Point in July 1992 (+SE)

Average mussel size at the Kasitsna Bay sites in early 1993 was $26.7 \pm 0.95 \mathrm{~mm}(\mathrm{n}=80)$ and mean density was $9460 \mathrm{~m}^{-2}$ ( $\mathrm{n}=10$ quadrats). The only pre-freeze data available for comparison are from 1986, at which time the average length was $56.0 \mathrm{~mm}(\mathrm{n}=816)$ and mean density was $1900 \mathrm{~m}^{-2}$ ( $\mathrm{n}=7$ quadrats) (R. C. Highsmith unpubl. data). Therefore, it appears that the demographic characteristics of the mussel population had changed from dominance by large individuals that filled the available space before the freeze to greater densities of small individuals since the freeze.

\section{Site-to-site variation in Nucella lima and Mytilus trossulus abundance}

In July 1992, mean Nucella lima density at Kasitsna Bay was high $\left(131.6 \pm 15.6 \mathrm{~m}^{-2}\right.$; range $=56$ to $\left.200 \mathrm{~m}^{-2}\right)$, while the density at Nubble Point, the isolated rocky outcropping $2 \mathrm{~km}$ distant, was significantly less $(2.8 \pm$ $4.4 \mathrm{~m}^{-2}$; range $=0$ to $16 \mathrm{~m}^{-2}$ ) (ANOVA: $\mathrm{df}=1,38, F=$ $211.8, \mathrm{p}<0.0001$ ) (Fig. 5). This drastic difference in

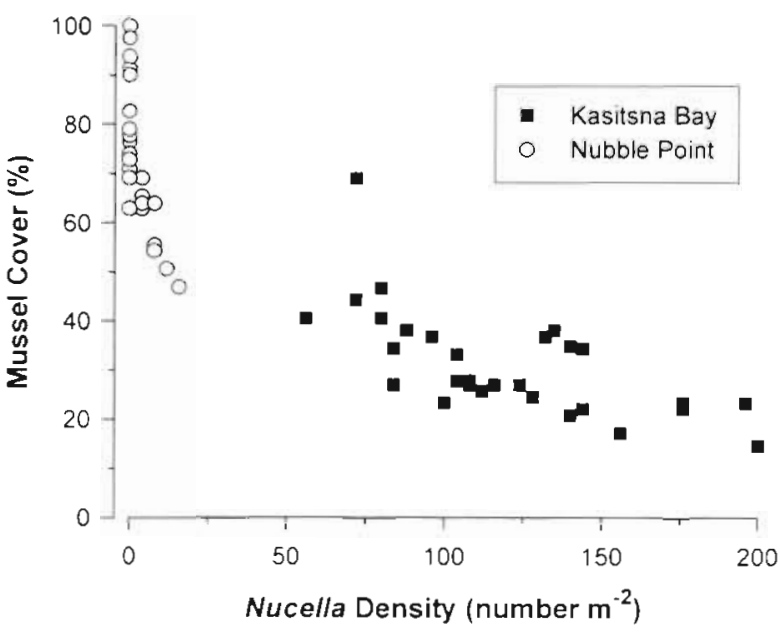

Fig. 6. Mussel cover relative to Nucella lima density at Kasitsna Bay and Nubble Point. The $y$-axis is slightly offset for graphical clarity

predator density at sites separated by only a small distance underscores the physical barrier to immigration caused by highly mobile substrates like sand and gravel. In contrast to the site-to-site pattern of $N$. lima mussel cover at Kasitsna Bay was less than half ( $31.4 \pm$ $2.0 \%)$ that at Nubble Point $(72.4 \pm 2.5 \%$ ) (ANOVA: $\mathrm{df}=$ $1,58, F=127.7, \mathrm{p}<0.0001$ ) (Fig. 5). This inverse pattern suggests that the presence of $N$. lima was negatively affecting mussel abundance. This hypothesis is further supported by the strong negative correlation between $N$. lima density and mussel cover in individual quadrats (Fig. 6).

\section{Sources of mussel mortality}

At the Kasitsna Bay site, Nucella lima predation is clearly a major source of mortality for mussels, with 73 to $81 \%$ of empty shells having drill holes (Table 1). In contrast to the large proportion of mussel mortality attributed to $N$. lima at Kasitsna Bay, the impact of $N$. lima predation was negligible at Nubble Point, with only 2 to $4 \%$ of empty mussel shells having been drilled (Table 1). This assessment method does not account for mortality sources, such as large waves or predation by gulls, ducks, or sea stars, which may remove mussel shells from the site. However, it is unlikely that such factors caused significant mortality at this site. Wave action, especially in summer, is minimal. Despite innumerable hours spent at the sites, avian predators were never observed removing mussels and the large tide range limits sea stars to levels on the shore that are well below the mussel distribution. There are potential limitations in inferring absolute mortality rates from dead shells; however, this method 
Table 1. Proportion of small $<25 \mathrm{~mm}$ length) and large (>25 mm length) empty mussel. shells at Kasitsna Bay and Nubble Point (Alaska, USA) whose mortality was attributed to Nucella lima predation. 'Drilled' shells exhibited a hole extending completely through the shell characteristic of gastropod predation, while no such hole existed in the 'Not drilled' class. Results are from observations on the first 100 empty shells in both size classes at each site

\begin{tabular}{|lccccc|} 
Shell & \multicolumn{2}{c}{ Kasitsna Bay } & \multicolumn{2}{c}{ Nubble Point } \\
condition & $<25 \mathrm{~mm}$ & $>25 \mathrm{~mm}$ & $<25 \mathrm{~mm}$ & $>25 \mathrm{~mm}$ \\
\hline Drilled & 73 & 81 & 2 & 4 \\
Not drilled & 27 & 19 & 98 & 96 \\
& & & & \\
\hline
\end{tabular}

provides a useful measure of relative site-to-site variation in predation pressure when great differences exist between sites, such as in this study.

\section{Impact of Nucella lima on mussel beds}

In the absence of Nucella lima predation, mussel cover in the cages remained essentially constant through the $8 \mathrm{wk}$ duration of the field caging study (Fig. 7). In contrast, average densities of $N$. lima resulted in significant losses of cover by mussels, compared to control cages containing no snails, within 2 wk of the initiation of the experiment (Fig. 7). Due to

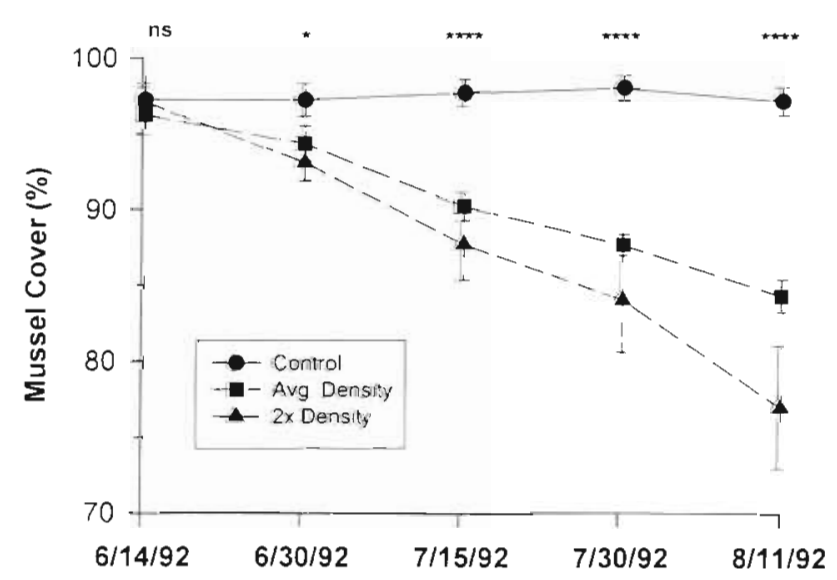

Fig. 7 Mussel cover ( $\pm 1 \mathrm{SE}$ ) through time in caged arenas containing different densities of Nucella lima $(n=8$ replicates per treatment). After arcsine square root transformation, control (no snails) and average density (5 snails) treatments were compared using 1-way ANOVAs testing for the main effect of predator density on mussel cover on each sampling date. Because the high density treatment (10 snails per cage) contained twice the density naturally found at the site, it is plotted for informational purposes only, and was not included in the statistical analysis. Probability of significance of main effects is as follows: ${ }^{\circ} p<0.05 ; \cdots p<0.01 ; \cdots p<0.001 ; \cdots p<$ $0.0001 ;$ ns $=$ not significant losses of cover of $1.6 \% \mathrm{wk}^{-1}$ by mussels in the average snail density treatment, the difference in cover between the 2 treatments steadily increased throughout the entire experiment. Although cages containing high densities of $N$. lima resulted in the greatest reductions of mussel cover of any of the treatments, the density of snails in the cages of that treatment was about twice that found naturally at the site. Therefore, the high density treatment was excluded from the statistical analysis contrasting the control and average density treatments but is also shown in Fig. 7 .

The initial mussel cover in all the cages exceeded $90 \%$. Consequently, snails sometimes became entrapped because mussels attached byssal threads to them. Entrapment can Iead to starvation of Nucella spp. under some circumstances (Petraitis 1987, Day et al. 1991). Typically, these snails feed at the edge of mussel beds and are less likely to be captured by byssal threads. Trapped snails were freed during censuses but their overall feeding efficiency was reduced. Therefore, the reduction in mussel cover observed in the 2 predation treatments (Fig. 7) is probably conservative.

\section{DISCUSSION}

The ability of an organism to respond to variation in its environment is of paramount importance to its success in a local community. The physiological resistance of mussels to sub-freezing temperatures allows them to withstand most freezing events encountered in temperate habitats (Williams 1970, Aarset 1982, Bourget 1983) and undoubtedly is a contributor to its persistence in such locations. However, the combination of a historic cold-snap, where the lowest temperature in over 70 yr was recorded in Homer, Alaska (NOAA 1994), and a spring low tide series resulted in extensive mortality of the local Mytilus trossulus population. Under the unusual circumstances dictated by this disturbance event, the behavioral adaptation of the Nucella lima to migrate into the subtidal zone during winter allowed it to largely escape the devastating mortality experienced by $M$. trossulus. The differential impact of the freeze event on these 2 species set the framework for a shift in the balance of their interaction.

The observational and experimental results of this study show an inverse correlation between predator density and prey abundance. Despite the ability of mussels to proliferate and occupy substrate via recruitment, growth, and immigration, predation by average Nucella lima densities in both manipulated and unmanipulated field experiments quickly resulted in significantly reduced mussel cover. Where snails are abundant (e.g. Kasitsna Bay), they are responsible for a large proportion of the mortality of their prey. At these 
sites, mussel populations were unable to increase their spatial occupation despite annual recruitment events (Fig. 3). Conversely, at an isolated outcropping effectively isolated from immigration to $N$. lima (e.g. Nubble Point), the predator was rare and resulting predation pressure was low. At this site, mussels were a dominant spatial component of the community. demonstrating the ability of Alaskan mussels to successfully recover from a major disturbance when released from heavy predation pressure.

Seed (1976) reported laboratory consumption rates for adult Nucella lapillus feeding on Mytilus edulis (10 to $30 \mathrm{~mm}$ in length) of 2.17 mussels $\mathrm{wk}^{-1}$. Extrapolating Seed's data to the present study with predator densities at Kasitsna Bay of $\sim 125$ snails $\mathrm{m}^{-2}$ and prey density of 9460 mussels $\mathrm{m}^{-2}, N$. lima could potentially consume $87 \%$ of the individuals in a continuous mussel bed in 30 weeks (the estimated mid-intertidal feeding season in south central Alaska). Based on the rate of reduction of mussel cover in the fenced feeding trials, the decline in mussel cover during a $30 \mathrm{wk}$ period would be $58 \%$. This is probably a conservative estimate because some of the fenced $N$. lima commonly became trapped among mussel byssal threads, reducing their feeding rates. In nature, snails do attack high-density populations of mussels, but they tend to do so from the edge of a patch so that they can retreat to a rock surface between feeding bouts. Even these conservative estimates of $N$. lima predation rates, however, demonstrate a strong inhibitory factor limiting recovery of the prey population.

Although mussel recovery rates may vary with several factors including timing of the disturbance and spatial extent of the disturbed patch, the recovery of mussels from disturbance is considered to be deterministic (Paine \& Levin 1981, Suchanek 1981, 1986, Paine 1984, Seed \& Suchanek 1992). For example, in New England (USA), Lubchenco \& Menge (1978) demonstrated that mussel beds on exposed shores are extremely susceptible to removal by winter storms. However, settlement processes, fast growth rates, and superior competitive ability usually led to recovery and mussel dominance by the end of the summer following removal. This cycle of winter removal and summer recovery, they suggested, is more or less an annual event and emphasizes how rapidly mussels may recover from disturbance and monopolize large expanses of intertidal substrate. Furthermore, in Oregon (USA), Menge et al. (1994) documented the invasion of Mytilus trossulus to a disturbed site and observed spatial dominance of previously free space within 9 mo. In contrast to those systems, where rapid recovery of mussel populations was evident, recovery of mussels to spatial dominance did not occur during a period of more than 3 yr at sites with high Nucella lima densities. Of course, other factors besides predation, such as insufficient numbers of surviving adults as a source population for larvae or lack of filamentous algae needed for primary plantigrade settlement, could have potentially contributed to the observed lack of recovery at Kasitsna Bay. However, the field data argues against these alternatives. Surviving adult populations in the extreme low intertidal zone and/or long-distance dispersal of larvae from other regions not as severely affected by the freeze were likely sources of the larval pool. Additionally, bare rock surface was rare during the recruitment season, and filamentous algae on which larvae attach was common (Carroll 1994). Further, it is improbable that the minimal mussel recovery was due to limited recruitment because moderate increases in cover attributable to mussel recruitment were evident early each summer at Kasitsna Bay and Hesketh Island (Fig. 3) before those gains disappeared later in the year. Growth rates of young mussels, while possibly reduced by the cold waters of south central Alaska, were clearly sufficient to allow the population at Nubble Point to dominate space in the absence of predation.

In addition to limited recovery of primary space, demographic characteristics of mussel populations where predators were abundant remained altered compared to pre-freeze levels. Mean mussel size during 1993 was less than half that in 1986 (26.7 vs $56.0 \mathrm{~mm}$ ), indicating a shift in the size-structure in the prey population toward smaller mussels more vulnerable to predation.

The importance of physical forcing functions in affecting community structure through alteration of predator-prey interactions has been elegantly developed in a series of papers examining community structure in New England (Menge 1976, 1978a, b, 1983, Lubchenco \& Menge 1978, Menge \& Lubchenco 1981). At locations protected from heavy wave action, predators significantly influenced the lower limit of Mytilus edulis distribution. In locations exposed to heavy wave action, predator densities were reduced, making them ineffective at controlling mussel densities, so $M$. edulis achieved long-term spatial dominance. In New England, instead of a stochastic, severe disturbance event as in this study, the physical forcing function was relatively predictable and chronic and varied along a gradient (from low to high wave exposure).

Acute physical disturbances clearly have the potential to alter the structure of impacted communities. Ecologists have often been principally concerned with the immediately apparent and direct effects of disturbances. Indirect effects, such as mediation of species interactions, are more subtle but can be as important to long-term community structure as direct effects (Strauss 1991, Hughes 1994, Wootton 1994, Menge 
1995). In the present study, a severe freeze altered predisturbance predator-prey interactions through differential mortality of the interactors. The ensuing shift in the dynamic relationship of predator-prey interactions resulted in an established Nucella lima population overwhelming annual Mytilus trossulus recruitment. Thus, predator control of mid-intertidal mussel populations was dictated by a catastrophic physical disturbance.

Acknowiedgements. The authors thank R. Geagel for assistance in the field and the Kasitsna Bay Committee for allowing use of the Kasitsna Bay Laboratory. P. Quang provided statistical advice. J. Carroll and several anonymous reviewers made thoughtful comments on the manuscript. The temperature data were generated by NOAA and provided by the Alaska State Climate Center, Environmental and Natural Resources Institute, University of Alaska, Anchorage. The Musée Océanographique in Monaco and the International Atomic Energy Agency in Vienna generously made available their library resources. This research was supported by the University of Alaska Fairbanks, the University of Alaska Foundation, Alaska Sea Grant, the U.S. Forest Service, and the Lerner-Gray Fund for Marine Research and the LincolnElsworth Fund, both of the American Museum of Natural History.

\section{LITERATURE CITED}

Aarset AV (1982) Freezing tolerance in intertidal invertebrates (a review). Comp Biochem Physiol 73A:571-580

Bourget E (1983) Seasonal variations and cold tolerance in intertidal mollusks and their relationship to environmental conditions in the St. Lawrence estuary. Can J Zool 61. 1193-1201

Bowman RS, Lewis JR (1977) Annual fluctuations in the recruitment of Patella vulgata L. J Mar Biol Ass UK 57 : $793-815$

Carriker MR, van Zandt D (1972) Predatory behavior of a shell boring muricid gastropod. In: Winn HE, Olla BL (eds) Behavior of marine animals, Vol 1, Invertebrates. Plenum Press, New York, p 157-176

Carroll ML (1994) The ecology of a high-latitude rocky intertidal community: processes driving population dynamics in Kachemak Bay, Alaska. PhD dissertation, University of Alaska Fairbanks

Connell JH (1978) Diversity in tropical rainforests and coral reefs. Science 199:1302-1310

Day RW, Barkai A, Wickens PA (1991) Trapping of three drilling whelks by two species of mussel. J Exp Mar Biol Ecol 149:109-122

Dethier MN (1984) Disturbance and recovery in intertidal pools: maintenance of mosaic pattern. Ecol monogr 54 : $99-118$

Feder HM, Keiser GE (1980) Intertidal biology. In: Colonell JM (ed) Port Valdez, Alaska: environmental studies 1976-1979. Institute of Marine Science, University of Alaska Fairbanks, p 143-224

Feder HM, Mueller GJ, Keiser GE (1977) A study of the intertidal region of Port Valdez, Prince William Sound Alaska. Institute of Marine Science Annual Report, University of Alaska Fairbanks

Gosling E (ed) (1992) The mussel Mytilus: ecology, physiology, genetics and culture. Elsevier, Amsterdam
Harper JL (1977) Population biology of plants. Academic Press, London

Hughes TP (1994) Catastrophes, phase shifts, and large-scale degradation of a Caribbean coral reef. Science 265: $1547-1551$

Kincaid T (1964) Notes on Thais (Nucella) lima (Gmelin), A marine gastropod inhabiting areas of the North Pacific Ocean. The Calliostoma Company, Seattle

Knowlton N, Lang JC, Rooney MC, Clifford P (1981) Evidence for delayed mortality on hurricane-damaged Jamaican staghorn corals. Nature 294:251-252

Koehn RK (1991) The genetics and taxonomy of species in the genus Mytilus. Aquaculture 94:125-145

Lewis JR, Bowman RS, Kendall MA, Williamson P (1982) Some geographical components of population dynamics: possibilities and realities in some littoral species. Neth $\mathrm{J}$ Sea Res 16:18-28

Lubchenco J, Menge BA (1978) Community development and persistence in a low rocky intertidal zone. Ecol Monogr 59: $67-94$

McDonald JH, Koehn RK (1988) The mussels Mytilus galloprovincialis and $M$. trossulus on the Pacific coast of North America. Mar Biol 99:111-118

McDonald JH, Seed R, Koehn RK (1991) Alloenzymes and morphometric characters in three species of Mytilus in the northern and southern hemispheres. Mar Biol 111: $323-333$

Menge BA (1976) Organization of the New England rocky intertidal community: role of predation, competition, and environmental heterogeneity. Ecol Monogr 46:355-393

Menge BA (1978a) Predation intensity in a rocky intertidal community. Relation between predator foraging activity and environmental harshness. Oecologia 34:1-16

Menge BA (1978b) Predation intensity in a rocky intertidal community. Effect of an algal canopy, wave action, and desiccation on predator feeding rates. Oecologia 34:17-35

Menge BA (1983) Components of predation intensity in the low zone of the New England rocky intertidal community. Oecologia 58:141-155

Menge BA (1995) Indirect effects in marine rocky intertidal interaction webs: patterns and importance. Ecol Monogr $65: 21-74$

Menge BA, Berlow EL, Blanchette CA, Navarette SA, Yamada SB (1994) The keystone species concept: variation in interaction strength in a rocky intertidal habitat. Ecol Monogr 64:249-286

Menge BA, Lubchenco J (1981) Community organization in temperate and tropical rocky intertidal habitats: prey refuges in relation to consumer pressure gradients. Ecol Monogr 51:429-450

National Oceanic and Atmospheric Administration (NOAA) (1994) National Weather Service records from Homer, Alaska. Data provided by the Alaska State Climate Center, Environmental and Natural Resources Institute, University of Alaska, Anchorage

O'Clair CE, Zimmerman ST (1987) Biogeography and ecology of intertidal and shallow subtidal communities. In: Hood DW, Zimmerman ST (eds) The Gulf of Alaska: physical environment and biological resources. National Oceanic and Atmospheric Administration. Anchorage, p 305-344

Paine RT (1966) Food web complexity and species diversity. Am Nat 100:65-75

Paine RT (1974) Intertidal community structure: experimental studies on the relationship between a dominant competitor and its principal predator. Oecologia 15:93-120

Paine RT (1984) Ecological determinism in the competition for space. Ecology $65: 1339-1348$ 
Paine RT, Levin SA (1981) Intertidal landscapes: disturbance and the dynamics of pattern. Ecol Monogr 51:145-178

Petraitis PS (1987) lmmobilization of the predatory gastropod, Nucella lapillus by its prey, Mytilus edulis. Bio Bull Mar Biol Lab, Woods Hole 172:307-314

Ricketts EF, Calvin J, Hedgepeth JW, Phillips DW (1985) Between Pacific tides, 5th edn. Stanford University Press, Stanford

Robles C, Sherwood-Stephens R, Alvarado M (1995) Responses of a key intertidal predator to varying recruitment of its prey. Ecology 76:565-579

Seed R (1969) The ecology of Mytilus edulis L. (Lamellibranchiata) on exposed rocky shores: II. Growth and mortality. Oecologia 3:317-350

Seed R (1976) Ecology. In: Bayne BL (ed) Marine mussels: their ecology and physiology. Cambridge University Press, Cambridge, p 13-65

Seed R, Suchanek TH (1992) Population and community ecology of Mytilus. In: Gosling E (ed) The mussel Mytilus: ecology, physiology, genetics and culture. Elsevier, Amsterdam, p 87-170

Sokal RR, Rohlf FJ (1981) Biometry, 2nd edn. WH Freeman, San Francisco

Soot-Ryen T (1955) A report on the family Mytilidae (Pelecypoda). Allan Hancock Pacif Exped 20:1-175

Sousa WP (1979) Disturbance in marine intertidal boulder fields: the non-equilibrium maintenance of species diver-

This article was submitted to the editor sity. Ecology 60:1225-1239

Sousa WP (1984) The role of disturbance in natural communities. A Rev Ecol Syst 15:353-391

Stephenson TA, Stephenson A (1972) Life between tidemarks on rocky shores. WH Freeman, San Francisco

Strauss SY (1991) lndirect effects in community ecology: their definition, study, and importance. Trends Ecol Evol 6: $206-210$

Suchanek TH (1978) The ecology of Mytilus edulis L. in exposed rocky intertidal communities. J Exp Mar Biol Ecol 31:105-120

Suchanek TH (1979) The Mytilus californianus community: studies on the composition, structure, organization, and dynamics of a mussel bed. PhD dissertation, University of Washington, Seattle

Suchanek TH (1981) The role of disturbance in the evolution of life history strategies of the intertidal mussels Mytilus edulis and Mytilus californianus. Oecologia 50:143-152

Suchanek TH (1986) Mussels and their role in structuring rocky shore communities. In: Moore PG, Seed R (eds) The ecology of rocky coasts. Columbia University Press, New York, p 70-96

Williams RJ (1970) Freezing tolerance in Mytilus edulis. Comp Biochem Physiol 35:145-161

Wootton JT (1994) The nature and consequences of indirect effects in ecological communities. A Rev Ecol Syst 25: $443-466$

Manuscript first received: November 6, 1995

Revised version accepted: March 19, 1996 